\title{
Effect of irrigation levels and foliar application of fertilizers on some agronomic and oil characteristics of castor bean (Ricinus communis L.)
}

\author{
Fardane Osati ${ }^{1}$, Toraj Mir Mahmoodi ${ }^{\star}$, Bahman Pasban Eslam², Samna Yazdan Seta ${ }^{1}$ \& Hassan Monirifar ${ }^{2}$
}

${ }^{1}$ Department of Agronomy, Mahabad Branch, Islamic Azad University, Mahabad, Iran

${ }^{2}$ Horticulture and Crops Research Department, East Azarbaijan Agricultural and Natural Resources Research and Education Center, AREEO, Tabriz, Iran

*Email: toraj73@yahoo.com

\section{OPEN ACCESS}

\section{ARTICLE HISTORY}

Received: 05 May 2021

Accepted: 23 June 2021

Available online

Version 1.0: 01 January 2022

\section{Check for updates}

Additional information

Peer review: Publisher thanks Sectional Editor and the other anonymous reviewers for their contribution to the peer review of this work.

Reprints \& permissions information is available at https://horizonepublishing.com/ journals/index.php/PST/open_access_policy

Publisher's Note: Horizon e-Publishing Group remains neutral with regard to jurisdictional claims in published maps and institutional affiliations.

Indexing: Plant Science Today, published by Horizon e-Publishing Group, is covered by Scopus, Web of Science, BIOSIS Previews, Clarivate Analytics, etc. See https:// horizonepublishing.com/journals/index.php/ PST/indexing_abstracting

Copyright: ( $)$ The Author(s). This is an openaccess article distributed under the terms of the Creative Commons Attribution License, which permits unrestricted use, distribution and reproduction in any medium, provided the original author and source are credited (https://creativecommons.org/licenses/ by/4.0/)

\section{CITE THIS ARTICLE}

Osati F, Mahmoodi T M, Eslam B P, Seta SY, Monirifar $\mathrm{H}$. Effect of irrigation levels and foliar application of fertilizers on some agronomic and oil characteristics of castor bean (Ricinus communis L.). Plant Science Today 2022;9(1):1-8. https://doi.org/10.14719/ pst.1250

\begin{abstract}
To study the effect of irrigation levels and foliar application of fertilizers on some agronomic and oil characteristics of castor bean, an experiment was conducted at the East Azarbaijan Agricultural Research and Education Center, Tabriz, Iran in 2017-2019 cropping seasons. The experiment was laid out as a split-plot design based on a completely randomized block design with three replications. In the present study, main cluster length, number of branches, number of capsules per plant, number of seeds per capsule, 100grain weight biological yield, grain yield, oil percent and oil yield were measured. Irrigation intervals (normal irrigation (irrigation after $60 \mathrm{~mm}$ ), irrigation after $80 \mathrm{~mm}$ and $140 \mathrm{~mm}$ of evaporation) was established as main plots and the foliar applications of fertilizers $(\mathrm{N}, \mathrm{K}, \mathrm{S}, \mathrm{N}+\mathrm{K}$, and $\mathrm{N}+\mathrm{S}, \mathrm{K}+\mathrm{S}$, $\mathrm{N}+\mathrm{K}+\mathrm{S}$ and control) input as sub-plots. The results showed that, except for the oil percentage, all the examined traits were decreased by water limitation. The highest values of the traits, other than the 100 -grain weight, were obtained for foliar application of $\mathrm{N}+\mathrm{K}+\mathrm{S}$. This treatment improved the grain yield per unit area under normal irrigation and moderate irrigation and severe stresses by $62.76 \%, 41.46 \%$ and $28.98 \%$ respectively. Thus, the foliar application of S $(2000 \mathrm{ppm})+\mathrm{N}(3000 \mathrm{ppm})+\mathrm{K}(3000 \mathrm{ppm})$ fertilizer is the best treatment for mitigating some harmful effects of water deficit on castor bean.
\end{abstract}

\section{Keywords \\ Grain yield, nitrogen, oil percent, stresses, water deficit}

\section{Introduction}

Castor plant is a vegetable oil obtained from the seeds (Ricinus communis) (1). The common name castor oil, from which the plant gets its name, is probably comes originated in its use as a replacement for castoreum, a perfume base made from the dried perineal glands of beavers (2). Castor and its derivatives are used for manufacturing of soaps, lubricants, hydraulic and brake fluids, paints, dyes, coatings, inks, cold-resistant plastics, waxes and polishes, nylon, pharmaceuticals and perfumes (3). Castor oil is a droughtresistant crop and grows well in dry and warm areas upon receiving a rainfall of 500-750 mm. This plant has a wide range of adaptations and can grow in marginal areas exposed to drought and salinity. It requires an average temperature of $20-26^{\circ} \mathrm{C}$ and low humidity to produce higher yields (3). Plant yield and photosynthesis are negatively influenced by water deficit due to a series of morphological, physiological, biochemical and molecular differ- 
ences (4). Irrigation optimization is important for the production of fresh plants and grain yield because water is the main component of the fresh product and affects the quantity and quality of crop yield (5). The management of water and nutrients used in fertilizers is a major factor influencing plant growth. It has been reported that the highest grain yield was obtained in castor in normal irrigation conditions (1.0 times evapotraspiration), and with increasing water use, an almost linear increase in yield was observed (6). Moreover, the treatment with the highest water consumption (1.0 times evapotraspiration) yielded approximately $210 \%$ more seeds than the control without irrigation (6). Water deficit conditions reduce the absorption and transport of nutrients, and foliar application may the effect of irrigation levels and foliar application of fertilizers on some agronomic and oil characteristics of castor bean.

\section{Materials and Methods}

The experiment was conducted in the in 2017-2019 cropping seasons at the Experimental Field Area of East Azarbaijan Agricultural Research and Education Center, Tabriz, Iran which is located between $58^{\circ} 37^{\prime} \mathrm{N}$ latitude and $37^{\circ} 58^{\prime} \mathrm{E}$ longitude. The average annual rainfall was 236 $\mathrm{mm}$. The soil texture of the experimental plot was sandy loam and the result of soil analysis is shown in Table 1.

Table 1. Soil physical and chemical characteristics of the experimental site

\begin{tabular}{|c|c|c|c|c|c|c|c|c|c|c|c|c|c|c|c|}
\hline \multicolumn{7}{|c|}{ (mg/kg) } & \multirow{2}{*}{ \%Clay } & \multirow{2}{*}{$\%$ Silt } & \multirow{2}{*}{$\%$ Sand } & \multirow{2}{*}{$\begin{array}{c}P \\
(\mathrm{mg} / \mathrm{kg})\end{array}$} & \multirow{2}{*}{$\begin{array}{c}\mathrm{K} \\
(\mathrm{mg} / \mathrm{kg})\end{array}$} & \multirow{2}{*}{$\% O C$} & \multirow{2}{*}{ \%T.N.V } & \multirow{2}{*}{$\begin{array}{c}\text { EC } \\
\text { (ds/m) }\end{array}$} & \multirow{2}{*}{ pH } \\
\hline $\mathrm{S}^{-\mathrm{SO}_{4}}$ & $\mathrm{Mg}$ & B & Mn & $\mathrm{Zn}$ & $\mathrm{Cu}$ & $\mathbf{F e}$ & & & & & & & & & \\
\hline 22 & 200 & 2.1 & 5.9 & 0.49 & 1.82 & 6.6 & 10 & 40 & 50 & 7.1 & 187 & 0.61 & 17.12 & 6.81 & 7.62 \\
\hline
\end{tabular}

be an effective and efficient way to improve the availability of nutrients to plants. Foliar application of nutrition is the use of liquid fertilizers to plant leaves. It was reported that the fertilizer foliar application method is widely employed to correct nutritional deficiencies in plants due to an inadequate supply of nutrients to the roots (7).

NPK fertilizers as foliar applications significantly increase the yield by increasing the plant biomass (8). The positive effect of the foliar application of nitrogen $(\mathrm{N})$, phosphorus $(\mathrm{P})$ and potassium $(\mathrm{K})$ to maintain proper leaf nutrition and carbon balance and improve photosynthesis capacity has been well established (9). Foliar application of essential nutrients and micronutrients such as NPKS and $B$ (Boron) is more beneficial than soil application and prevents the reduction of these nutrients in the leaves, thereby increasing the rate of photosynthesis and leading to a better transfer of these nutrients from the leaves to the growing seeds (10). It was reported that foliar application is credited with the advantage of fast, efficient and effective use of nutrients, eliminates losses through leaching and stabilization and helps regulate the absorption of nutrients by plants (11). It has been reported that foliar application of fertilizer in the early vegetative stages of soybean increases the grain yield in $15-30 \%$ of fields, depending on the year (12). It was showed that the highest grain yield, biological yield and oil yield were obtained in the treatment of $80 \mathrm{~kg} / \mathrm{ha} \mathrm{N}$ in medicinal and aromatic plants (13).

In previous studies, only the effect of foliar application of micro or macro-elements on the growth characteristics and yield of plants was investigated, and the effect of combining these elements as the foliar application in different environmental conditions has been neglected. Also, in previous studies, the soil application of chemical fertilizers on the growth characteristics of castor bean was investigated, while foliar application of chemical fertilizers and its effect on the characteristics of this plant and their role on the response of plants to water deficit was not studied. Therefore, the present study aimed to examine
The experiment was laid out as a split-plot design based on a completely randomized block design with three replications. Irrigation intervals of normal irrigation (irrigation after $60 \mathrm{~mm}$ ), irrigation after $80 \mathrm{~mm}$ (Mild stress) and after $140 \mathrm{~mm}$ of evaporation (Severe stress) from class A pan were placed in the main plots, and foliar applications of fertilizers ( $N(3000$ ppm), K (3000 ppm), S (2000 ppm), $\mathrm{N}+\mathrm{K}$, and $\mathrm{N}+\mathrm{S}, \mathrm{K}+\mathrm{S}, \mathrm{N}+\mathrm{K}+\mathrm{S}$ and control) were allocated to the sub-plots which were sprayed in the grain filling stage.

For the foliar application of N, K and sulfur (S) elements, respectively urea fertilizer at a rate of $3000 \mathrm{ppm}$, triple superphosphate at a rate of 3000 ppm (60 g per $20 \mathrm{l}$ of water) and vegetable $S$ at a rate of 2000 ppm ( $40 \mathrm{~g}$ per 20 I of water) were used with a special sprayer equipped with a liquid powder nozzle. The foliar application was performed at the stage of grain filling (In August, ninety days after planting).

Irrigation water was estimated using Type III flumes (Washington State College). The mouth width and head of III flumes were 304.8 and $30 \mathrm{~mm}$ respectively. Seeds were treated with thiram (tetramethyl thiuram disulfide) (5 per thousand) before sowing because there is a risk of low spring temperature and high soil moisture immediately after sowing.

Local castor bean varieties were planted $100 \mathrm{~cm}$ apart, keeping a distance of $50 \mathrm{~cm}$ between the rows. The main plot size was $3 \mathrm{~m} \times 20 \mathrm{~m}=60 \mathrm{~m}^{2}$ and the sub-plot sizes were $3 \mathrm{~m} \times 4 \mathrm{~m}=12 \mathrm{~m}^{2}$. Castor seeds were manually sown on 5 May both years.

Weed control was performed manually in two stages (the first stage when the plant was $20-25 \mathrm{~cm}$ height, and the second stage a month later from the first weeding). Harvesting was done when all the capsules were dried in castor manually (100 to 120 days after planting).

After removing the marginal effects, 10 plants from each plot were used as a sample to measure cluster length, main cluster length, number of branches, number of cap- 
sules per plant, number of seeds per capsule and hundred conditions modified the effect of low water stress on plant grain weight. The total plot was used to measure biological height (Table 4). The increase in the main cluster length yield and grain yield after removing the marginal effects. might have been due to the application of nutrients at later Also, seed oil (\%) was measured by the Soxhlet method (10 stages which increased the availability of nutrients for plant $\mathrm{g}$ per sample) and oil yield was obtained by multiplying growth and development and led to the better utilization of seed yield by the crude oil ratio (14).

the applied major and micro-nutrients. .

Statistical analysis was conducted with SAS 9.2 soft-

The positive effect of fertilizer foliar application on ware (15) and the mean of treatments was compared with increasing plant height has been reported in several studies Duncan's Multiple Range Test (DMRT) at a significance level (16-18). As reported, foliar K application increased plant of 0.01 . height in wheat when sprayed under drought at the vegetative stage (19).

\section{Results and Discussion}

\section{Number of branches}

\section{Main cluster length}

The effect of irrigation levels $(p<0.05)$ on the number of According to the results of the analysis of variance, the branches was significant (Table 2). Irrigation after 80 and differences between irrigation $(p<0.05)$, fertilizers $(p<0.01) 140 \mathrm{~mm}$ of evaporation decreased the number of branches and irrigation $\times$ fertilizers $(p<0.01$ ) were significant on the by 23.81 and $54.96 \%$ compared with normal irrigation main cluster length. The results obtained from the mean (Table 3). An increase in the number of seeds under normal comparison (Table 4) showed that the highest main cluster conditions mainly because of an increase in the number of length was allocated to the foliar application of $\mathrm{S}$ under fertile seeds and clusters per plant.

Table 4. Mean comparison of interaction effects of irrigation levels and foliar application fertilizers on studied traits of Castor

\begin{tabular}{|c|c|c|c|c|c|c|c|c|}
\hline Irrigation levels & $\begin{array}{l}\text { Foliar applica- } \\
\text { tion }\end{array}$ & $\begin{array}{l}\text { Main cluster } \\
\text { length } \\
\text { (cm) }\end{array}$ & $\begin{array}{c}\text { Number of } \\
\text { Capsule per } \\
\text { Plant }\end{array}$ & $\begin{array}{l}\text { Number of } \\
\text { Seeds per } \\
\text { Capsule }\end{array}$ & $\begin{array}{c}\text { Hundred } \\
\text { grain weight } \\
\text { (g) }\end{array}$ & $\begin{array}{l}\text { Biological } \\
\text { Yield } \\
\text { (t/ha) }\end{array}$ & $\begin{array}{c}\text { Grin yield } \\
\text { (t/ha) }\end{array}$ & $\begin{array}{l}\text { Oil yield } \\
\text { (Kg/ha) }\end{array}$ \\
\hline \multirow{8}{*}{ Normal } & S (2000ppm) & $69 a$ & 72.20a-e & $127.32 \mathrm{abc}$ & 21.93ab & $4.40 \mathrm{c}-\mathrm{f}$ & $1.11 b c$ & $450.59 c-i$ \\
\hline & K (3000ppm) & $47.27 \mathrm{~b}-\mathrm{g}$ & $75.60 \mathrm{abc}$ & $128.02 \mathrm{abc}$ & $18.33 \mathrm{bcd}$ & $3.90 \mathrm{c}-\mathrm{h}$ & $0.98 \mathrm{cde}$ & $412.99 \mathrm{e}-\mathrm{j}$ \\
\hline & N (3000ppm) & $66.45 a b$ & 68.33a-g & $129.64 a b$ & $18.70 \mathrm{bc}$ & $5.43 a b$ & $1.38 \mathrm{a}$ & $564.34 a b$ \\
\hline & $S+K$ & $60.52 a b$ & $77.53 a b$ & $130.52 a$ & $24.93 a$ & $4.54 \mathrm{~b}-\mathrm{e}$ & $1.15 b$ & $494.25 b c d$ \\
\hline & $\mathrm{S}+\mathrm{N}$ & $42.5 c-h$ & $69.86 a-f$ & 126.08a-e & $23.83 a$ & $4.67 \mathrm{bcd}$ & $1.15 b$ & $478.09 \mathrm{cde}$ \\
\hline & $\mathrm{K}+\mathrm{N}$ & 54.17a-e & $74.46 a-d$ & 125.34a-e & $15.16 c-h$ & $6.23 a$ & $1.48 a$ & $635.75 a$ \\
\hline & $\mathrm{S}+\mathrm{N}+\mathrm{K}$ & $55.67 a-d$ & $79.33 a$ & $129.76 a b$ & $17.20 \mathrm{e}-\mathrm{i}$ & $5.95 a$ & $1.53 a$ & $628.6 a$ \\
\hline & Control & 44.95b-h & $62.40 \mathrm{e}-\mathrm{i}$ & $122.30 a-f$ & $13.50 f-i$ & $3.79 \mathrm{c}-\mathrm{i}$ & 0.95def & $466.26 \mathrm{c}-\mathrm{g}$ \\
\hline \multirow{7}{*}{$\begin{array}{l}\text { Irrigation after } 80 \mathrm{~mm} \text { evapora- } \\
\text { tion }\end{array}$} & S (2000ppm) & $42 c-h$ & $56.8 \mathrm{~g}-\mathrm{j}$ & $118.62 \mathrm{c}-\mathrm{g}$ & $16.33 c-f$ & $3.55 f-j$ & $0.89 \mathrm{~d}-\mathrm{g}$ & $418.47 \mathrm{~d}-\mathrm{j}$ \\
\hline & $\mathrm{N}(3000 p p m)$ & $48.5 b-g$ & $63.20 \mathrm{~d}-\mathrm{i}$ & $113.84 \mathrm{fg}$ & $13.26 f-i$ & $4.08 \mathrm{c}-\mathrm{g}$ & $1.03 \mathrm{bcd}$ & $517.59 b c$ \\
\hline & $S+K$ & $37.83 \mathrm{~d}-\mathrm{j}$ & $62.53 \mathrm{e}-\mathrm{i}$ & $116.08 \mathrm{efg}$ & $14.56 \mathrm{~d}-\mathrm{i}$ & $3.84 \mathrm{c}-\mathrm{i}$ & $0.97 c-f$ & $462.74 \mathrm{c}-\mathrm{g}$ \\
\hline & $\mathrm{S}+\mathrm{N}$ & 29.5hij & $68.40 \mathrm{c}-\mathrm{i}$ & $115.90 \mathrm{efg}$ & $18.80 \mathrm{bc}$ & $3.31 c-j$ & $0.83 e-i$ & $449.89 c-i$ \\
\hline & $\mathrm{K}+\mathrm{N}$ & $52.17 a-f$ & $63.80 \mathrm{c}-\mathrm{i}$ & $126.51 a-d$ & $13.70 f-i$ & $3.64 e-j$ & $0.88 \mathrm{~d}-\mathrm{g}$ & $468.87 c-f$ \\
\hline & $\mathrm{S}+\mathrm{N}+\mathrm{K}$ & $59.45 a b c$ & 71.46a-e & $119.20 c-f$ & 11.76ghi & $4.70 b c$ & $1.16 \mathrm{~b}$ & $521.48 \mathrm{bc}$ \\
\hline & Control & $49.9 b-g$ & 50.33jk & $112.32 \mathrm{fg}$ & $10.80 \mathrm{i}$ & $3.42 f-j$ & $0.82 \mathrm{f}-\mathrm{i}$ & $396.75 f-j$ \\
\hline \multirow{7}{*}{$\begin{array}{l}\text { Irrigation after } 140 \mathrm{~mm} \text { evapora- } \\
\text { tion }\end{array}$} & S (2000ppm) & $22.67 \mathrm{ij}$ & $56.20 \mathrm{~h}-\mathrm{k}$ & $113.92 \mathrm{fg}$ & 12.33ghi & $2.94 \mathrm{hij}$ & $0.70 \mathrm{hij}$ & 379.75hij \\
\hline & K (3000ppm) & $33.33 f-j$ & $59.46 f-g$ & $119.36 c-f$ & $13.23 \mathrm{f}-\mathrm{i}$ & $2.98 \mathrm{ig}$ & $0.64 j$ & 382.43hij \\
\hline & N (3000ppm) & $34.83 f-j$ & $53.86 i j k$ & $117.24 \mathrm{~d}-\mathrm{g}$ & $12.56 \mathrm{f}-\mathrm{i}$ & $2.88 \mathrm{ij}$ & $0.69 \mathrm{ij}$ & $373.97 \mathrm{ij}$ \\
\hline & $S+K$ & $41.33 c-i$ & $65.46 \mathrm{c}-\mathrm{i}$ & $120.80 \mathrm{~b}-\mathrm{f}$ & $15.36 \mathrm{c}-\mathrm{g}$ & $3.30 \mathrm{~g}-\mathrm{j}$ & $0.79 \mathrm{~g}-\mathrm{j}$ & $401.31 \mathrm{e}-\mathrm{j}$ \\
\hline & $\mathrm{S}+\mathrm{N}$ & $22.5 i-j$ & $65.53 \mathrm{c}-\mathrm{i}$ & $118.68 \mathrm{c}-\mathrm{g}$ & $14.80 \mathrm{~d}-\mathrm{h}$ & $3.14 \mathrm{~g}-\mathrm{j}$ & $0.75 \mathrm{~g}-\mathrm{j}$ & $391.17 \mathrm{~g}-\mathrm{j}$ \\
\hline & $\mathrm{S}+\mathrm{N}+\mathrm{K}$ & $32.67 \mathrm{~g}-\mathrm{j}$ & $58.00 f-j$ & $118.78 \mathrm{c}-\mathrm{g}$ & $17.60 \mathrm{cde}$ & $3.70 \mathrm{~d}-\mathrm{i}$ & $0.89 \mathrm{~d}-\mathrm{g}$ & $453.82 c-h$ \\
\hline & Control & $36.67 e-j$ & $44.86 \mathrm{k}$ & $109.58 \mathrm{~g}$ & $11.53 \mathrm{hi}$ & $2.70 \mathrm{j}$ & 0.69ij & $340.92 j$ \\
\hline
\end{tabular}

In each column, averages with common character do not have a significant difference at the $5 \%$ level.

normal irrigation with an average of $69 \mathrm{~cm}$. However, there was no significant difference between the mentioned treatment and the foliar application of $\mathrm{N}, \mathrm{S}+\mathrm{K}, \mathrm{N}+\mathrm{K}$ and $\mathrm{N}+\mathrm{K}+$ $S$ under normal conditions and foliar application of $N+K$ and $\mathrm{N}+\mathrm{K}+\mathrm{S}$ under irrigation after $80 \mathrm{~mm}$ of evaporation. Therefore, the spraying of these elements under mild stress
In a study it was stated that the decrease in the number of branches in water limitation may be due to the reduction of cell growth and leaf senescence resulting from turgor pressure, or due to reduced photosynthesis and changes in the canopy structure in water deficit conditions $(20,21)$. It was also reported that the decrease in plant 
Table 2. Combine analysis of variance of irrigation and spraying chemical fertilizers on studied traits in Castor bean

\begin{tabular}{|c|c|c|c|c|c|c|c|c|c|c|}
\hline \multirow[b]{2}{*}{ Resource changes } & \multirow[b]{2}{*}{ Df } & \multirow[b]{2}{*}{$\begin{array}{l}\text { Main cluster } \\
\text { length }\end{array}$} & \multicolumn{5}{|c|}{ Mean square } & \multirow[b]{2}{*}{ Grin yield } & \multirow[b]{2}{*}{ Oil percent } & \multirow[b]{2}{*}{ Oil yield } \\
\hline & & & $\begin{array}{l}\text { Number of } \\
\text { branches }\end{array}$ & $\begin{array}{l}\text { Number of } \\
\text { Capsule per } \\
\text { Plant }\end{array}$ & $\begin{array}{l}\text { Number of Seeds } \\
\text { per Capsule }\end{array}$ & $\begin{array}{l}\text { Hundred } \\
\text { grain } \\
\text { weight }\end{array}$ & $\begin{array}{l}\text { Biological } \\
\text { yield }\end{array}$ & & & \\
\hline Year $(Y)$ & 1 & $807.60^{\text {ns }}$ & $0.08^{\mathrm{ns}}$ & $0.358^{\mathrm{ns}}$ & $71.70^{\text {ns }}$ & $4.46^{\mathrm{ns}}$ & $0.12^{\mathrm{ns}}$ & $0.79^{\text {ns }}$ & $10.19^{\text {ns }}$ & $4692.3^{\text {ns }}$ \\
\hline$Y(R)$ & 4 & 239.12 & 0.02 & 0.171 & 8.29 & 1.26 & 0.10 & 0.15 & 5.21 & 1251.23 \\
\hline Irrigation levels (I) & 2 & $1650.20^{\star}$ & $6.40^{\star}$ & $163.22^{\star}$ & $485.57^{\star}$ & $189.55^{\star \star}$ & $19.85^{\star \star}$ & $1.24^{\star \star}$ & $761.34^{\star \star}$ & $90449.5^{\star \star}$ \\
\hline$Y \times 1$ & 2 & $349.65^{\text {ns }}$ & $1.05^{\mathrm{ns}}$ & $68.39^{\text {ns }}$ & $96.87^{\mathrm{ns}}$ & $6.59^{\text {ns }}$ & $1.13^{\text {ns }}$ & $0.041^{\mathrm{ns}}$ & $59.06^{\text {ns }}$ & $10421.2^{\text {ns }}$ \\
\hline Error 1 & 12 & 199.05 & 0.66 & 21.44 & 67.68 & 7.82 & 0.63 & 0.039 & 21.23 & 8591.4 \\
\hline Foliar application (F) & 7 & $343.52^{\star \star}$ & 0.12 & $249.08^{\star \star}$ & $88.31^{\star \star}$ & $35.18^{\star \star}$ & $2.23^{\star \star}$ & $0.13^{\star \star}$ & $39.75^{\star \star}$ & $23055.8^{\star \star}$ \\
\hline$Y \times F$ & 7 & $60.56^{\mathrm{ns}}$ & $0.10^{\text {ns }}$ & $88.93^{\text {ns }}$ & $36.74^{\text {ns }}$ & $9.78^{\mathrm{ns}}$ & $0.53^{\text {ns }}$ & $0.011^{\mathrm{ns}}$ & $15.22^{\mathrm{ns}}$ & $985.21^{\text {ns }}$ \\
\hline $\mathrm{I} \times \mathrm{F}$ & 14 & $128.49^{* *}$ & $0.06^{\mathrm{ns}}$ & $206.22^{\star \star}$ & $60.13^{*}$ & $27.92^{\star \star}$ & $0.70^{\star}$ & $0.057^{\star}$ & $9.82^{\mathrm{ns}}$ & $3792.4^{\star \star}$ \\
\hline E2 & 83 & 50.74 & 0.07 & 55.43 & 29.67 & 5.33 & 0.32 & 0.020 & 14.20 & 1623.7 \\
\hline CV\% & - & 11.19 & 10.09 & 11.60 & 6.86 & 17.93 & 14.66 & 16.81 & 9.53 & 20.33 \\
\hline
\end{tabular}

ns, ${ }^{*}$, and ${ }^{\star \star}$ were on significant, significant at level 1 and $5 \%$ respectively

Table 3. Mean comparison of effect of irrigation levels and foliar application fertilizers on studied traits of Castor

\begin{tabular}{|c|c|c|c|c|c|c|c|c|c|}
\hline & $\begin{array}{l}\text { Main cluster } \\
\text { length }(\mathrm{cm})\end{array}$ & $\begin{array}{l}\text { Number of } \\
\text { branches }\end{array}$ & $\begin{array}{l}\text { Number of } \\
\text { Capsule per } \\
\text { Plant }\end{array}$ & $\begin{array}{c}\text { Number of Seeds } \\
\text { per Capsule }\end{array}$ & $\begin{array}{c}\text { Hundred } \\
\text { grain weight } \\
\text { (g) }\end{array}$ & $\begin{array}{l}\text { Biological } \\
\text { yield (t/ha) }\end{array}$ & $\begin{array}{l}\text { Grin yield } \\
\text { (t/ha) }\end{array}$ & Oil Percent & $\begin{array}{r}\text { Oil Yield } \\
\text { (Kg/ha) }\end{array}$ \\
\hline \multicolumn{10}{|l|}{ Irrigation levels } \\
\hline Normal & $55.07 a$ & $2.34 a$ & $66.38 a$ & $125.78 a$ & $18.82 \mathrm{a}$ & $4.87 a$ & $1.22 \mathrm{a}$ & $42.50 \mathrm{c}$ & $516.52 a$ \\
\hline $\begin{array}{l}\text { Irrigation after } 80 \mathrm{~mm} \\
\text { evaporation }\end{array}$ & $45.21 b$ & $1.89 a b$ & $64.81 \mathrm{ab}$ & $119.05 a b$ & $14.32 b$ & $3.74 b$ & $0.93 b$ & $49.30 \mathrm{~b}$ & $457.36 \mathrm{~b}$ \\
\hline \multicolumn{10}{|l|}{ Foliar application } \\
\hline S (2000ppm) & $44.56 a b$ & $1.97 a$ & $57.48 d$ & $120.98 \mathrm{ab}$ & $16.60 \mathrm{bc}$ & 3.36cde & $0.90 \mathrm{~d}$ & $48.25 b c$ & 426.74de \\
\hline $\mathrm{K}(3000 \mathrm{ppm})$ & $40.98 \mathrm{bc}$ & $1.73 a$ & $63.97 \mathrm{bcd}$ & $122.0 \mathrm{ab}$ & $15.64 \mathrm{bcd}$ & $3.32 \mathrm{e}$ & $0.82 \mathrm{e}$ & $47.38 \mathrm{bc}$ & $383.55 \mathrm{e}$ \\
\hline N (3000ppm) & 49.93ab & $1.72 \mathrm{a}$ & $61.80 \mathrm{~cd}$ & $122.26 \mathrm{ab}$ & $14.84 \mathrm{cde}$ & $4.15 b c$ & $1.04 \mathrm{~b}$ & $47.13 c$ & $485.30 \mathrm{bc}$ \\
\hline $\mathrm{S}+\mathrm{K}$ & $42.06 \mathrm{bc}$ & $1.83 a$ & $60.11 \mathrm{~cd}$ & $121.72 \mathrm{ab}$ & 17.27ab & $3.91 \mathrm{bcd}$ & $0.97 b c$ & $48.33 c$ & $452.77 \mathrm{~cd}$ \\
\hline $\mathrm{K}+\mathrm{N}$ & $53.7 a$ & $1.90 a$ & $59.17 d$ & $119.05 \mathrm{ab}$ & $13.47 \mathrm{de}$ & 4.31ab & $1.03 \mathrm{~b}$ & $48.00 \mathrm{c}$ & 510.45 \\
\hline $\mathrm{S}+\mathrm{N}+\mathrm{K}$ & $43.84 a b$ & $1.72 \mathrm{a}$ & $73.44 a$ & $125.03 a$ & $14.52 \mathrm{cde}$ & $4.78 a$ & $1.19 a$ & $52.19 a$ & $535.05 a$ \\
\hline Control & $31.5 c$ & $1.75 a$ & $66.33 \mathrm{bc}$ & $114.23 b$ & $13.31 \mathrm{e}$ & 3.36de & $0.84 \mathrm{e}$ & $45.69 c$ & 423.93de \\
\hline
\end{tabular}

In each column, averages with common character do not have a significant difference at the $5 \%$ level.

growth is associated with a decrease in photosynthesis due to a reduction in stomatal conductance (22).

\section{Number of capsules per plant}

Irrigation levels $(p<0.05)$, fertilizers $(p<0.01)$ and the interaction between them $(p<0.01)$ significantly affected the number of capsules per plant (Table 2). The results showed that water deficit significantly reduced the number of capsules per plant, but this decline was less in fertilizer treatments. The number of capsules per plant was highest in the foliar application of $\mathrm{N}+\mathrm{P}+\mathrm{K}$ under normal conditions with an average of 79.33 ; however, there was no significant difference between $\mathrm{N}+\mathrm{P}+\mathrm{K}$ treatment and all fertilizer treatment under normal conditions, and the minimum value was recorded from non-spraying of fertilizer under irrigation after $140 \mathrm{~mm}$ of evaporation (44.86) (Table 3). The results also showed that foliar application of K), N, S + K, S + $\mathrm{N}, \mathrm{K}+\mathrm{N}$ and $\mathrm{S}+\mathrm{N}+\mathrm{K}$ significantly increased the number of pods under irrigation after $80 \mathrm{~mm}$ of evaporation, respec- tively by $32.18,25.57,24.24,35.90,26.76$ and $41.89 \%$ compared with control treatment. Furthermore, under irrigation after $140 \mathrm{~mm}$ of evaporation, foliar application of $\mathrm{K}, \mathrm{S}+$ $\mathrm{K}, \mathrm{S}+\mathrm{N}$ and $\mathrm{S}+\mathrm{N}+\mathrm{K}$ increased the number of pods by $32.54,45.92,46.07$ and 29.29 in respective order. Therefore, the application of $\mathrm{K}, \mathrm{S}+\mathrm{K}, \mathrm{S}+\mathrm{N}$ and $\mathrm{S}+\mathrm{N}+\mathrm{K}$ fertilizers in all moisture conditions had a positive effect on increasing the number of castor pods (Table 4). When the plant is provided with optimum irrigation, it will experience greater vegetative growth such as main cluster length and number of branches and produce more branches and thus the number of capsules is increased (23). Reports are on the number of capsules in castor increases with decreasing the drought stress (6). Previous research has demonstrated that the foliar application of fertilizer significantly increases the number of pods per plant $(16,17,24,25)$. It can be stated that the supply of water and minerals in the present study had a positive effect on the number of capsules per plant. 


\section{Number of seeds per capsule}

The effects of irrigation levels $(p<0.05)$ and fertilizers $(p<$ $0.01)$ and the interaction of irrigation $\times$ fertilizers $(p<0.01)$ on the number of seeds per capsule were significant (Table 2). The results (Table 4) showed that by increasing the irrigation intervals, the grain number in all fertilizer treatments was decreased, such that the highest number of grains was observed under normal irrigation. The highest grain number (130.52) was obtained in spraying of $\mathrm{S}+\mathrm{K}$ fertilizer under normal condition and the lowest number (109.58) was observed in the control of fertilizer with irrigation after $140 \mathrm{~mm}$ of evaporation. Furthermore, the foliar application of $\mathrm{K}+\mathrm{N}$ fertilizer in irrigation after $80 \mathrm{~mm}$ of evaporation had a positive effect on grain number and increased grain number by $15.15 \%$ compared with the control treatment in the same condition. However, in the case of irrigation after $140 \mathrm{~mm}$ of evaporation, the foliar application did not have a significant effect on the number of grains. It seems that foliar application of chemical fertilizers under water availability treatments has increased root development and improved nutrient uptake and transfer to the reproductive parts of the plant, Also, under normal conditions, Infertile pollen and female in flowers decreased and the number of grains increased. In a study, the number of seeds in Nigella sativa was reduced by intensifying water deficit stress (23). It was found that the number of grains spike $^{-1}$ increased to maximum (230) with three sprays of NPK, followed by two sprays (213), while the minimum number of grains spike ${ }^{-1}$ was produced by the control (198) (26). Numerous studies have shown that the number of seeds is positively affected by foliar application of fertilizers $(16,27)$.

\section{Hundred grain weight}

Based on the results of the analysis of variance (Table 2), the hundred grain weight was significantly affected by irrigation levels $(p<0.01)$, fertilizers $(p<0.01)$, and the interaction of these two treatments $(p<0.01)$. The results (Table 4$)$ indicated that the highest 100 -grain weight was gained from the foliar application of $\mathrm{S}+\mathrm{K}$ and $\mathrm{S}+\mathrm{N}$ under normal condition by 24.93 and 23.83 g respectively and the lowest value was observed in the non-foliar application under irrigation after $80 \mathrm{~mm}$ of evaporation by $10.80 \mathrm{~g}$. In all three irrigation conditions, application of $\mathrm{S}+\mathrm{N}$ had the most positive effect on grain weight gain, such that this treatment increased seed weight in normal and irrigation conditions after 80 and $140 \mathrm{~mm}$ of evaporation by 76.51, 80 and $28.36 \%$ respectively, compared to the control treatment in the same conditions.

Therefore, it can be concluded that the foliar application of fertilizer under moderate water deficit conditions has the most positive effect on grain weight. Also, with an increase in the photosynthetic rate as a result of spraying anti-transpiration compounds, in the seed formation time, the plant allocates more assimilates to the seed, thereby increasing the weight of seeds.

It was found that three sprays of the combination of NPK had the highest grain weight, while the control treatment produced grains with the least weight in the wheat crop in Peshawar (26). Previous research has emphasized the role of fertilizer foliar application in increasing grain weight (18), while some researchers have stated that the effect of fertilizer foliar application on grain weight is not significant $(17,28)$.

\section{Biological yield}

The effects of irrigation levels $(p<0.01)$ and fertilizers $(p<$ $0.01)$, and the interaction of irrigation $\times$ fertilizers $(p<0.05)$ were significant on biological yield (Table 2). The results (Table 4) indicated that the maximum biological yield was recorded from the foliar application of $\mathrm{K}+\mathrm{N}$ and $\mathrm{S}+\mathrm{N}+\mathrm{K}$ fertilizer by 6.23 and 5.95 ton/ha, whereas the minimum one was gained from the control of fertilizer under irrigation after $140 \mathrm{~mm}$ of evaporation by 2.70 ton/ha. Under normal conditions, the foliar application of $\mathrm{N}, \mathrm{S}+\mathrm{K}, \mathrm{S}+\mathrm{N}$ and $\mathrm{S}+\mathrm{N}+\mathrm{K}$ significantly increased biological yield compared to the control treatment in the same condition. In irrigation after $80 \mathrm{~mm}$ of evaporation, there was a significant difference between control treatment and foliar application of $\mathrm{N}, \mathrm{S}+\mathrm{K}$ and $\mathrm{S}+\mathrm{N}+\mathrm{K}$ treatment fertilizers, As a result, these treatments increased the biological yield by $19.29,12.28$ and $37.42 \%$ compared to the control treatment. Under irrigation after $140 \mathrm{~mm}$ of evaporation, the only significant difference was observed between the control treatment and foliar application of $\mathrm{S}+\mathrm{N}+\mathrm{K}$ fertilizer; this treatment increased biological yield by $37.30 \%$ compared to the control. The increase in the dry matter at combined foliar-applied nutrients might have been due to the increased uptake of all the nutrients which, in turn, helped plant growth, increased branches, and led to the retention of pods and adequate supply of nutrients, which increased the carboxylation efficiency and the ribulose- 1-5 diphosphate carboxylase activity, resulting in an increased photosynthetic rate.

It was reported that delaying the phenological development while increasing the number of leaves and plant height through foliar urea spray increased biological yield in maize (29). They also found that plant height, leaf area, number of grains per cob and per line as well as (1000) grain weight and grain and stover yields increased significantly up to the $6 \%$ urea level.

Late-season foliar $\mathrm{N}$ and $\mathrm{P}$ application in wheat influenced straw yield (30). It was also found that three sprays of the combined use of NPK resulted in the highest biological yield, followed by two sprays, while the control (water spray) treatment produced grains with the lowest weight in the wheat crop in Peshawar (26).

\section{Grain yield}

The results (Table 2 ) indicated that the effects of irrigation levels $(p<0.01)$ and fertilizers $(p<0.01)$, and the interaction of irrigation $\times$ fertilizers $(p<0.05)$ on grain yield were significant. Based on the findings, under normal irrigation, the highest grain yield was gained from the foliar application of $\mathrm{N}, \mathrm{K}+\mathrm{N}$ and $\mathrm{S}+\mathrm{N}+\mathrm{K}$ fertilizer by $1.38,1.48$ and 1.53 ton/ha which increased grain yield by $46.80,22.34$ and $23.40 \%$ compared to the control in respective order. With increasing the irrigation intervals, grain yield significantly decreased, but under irrigation after $80 \mathrm{~mm}$ of evaporation, 
the foliar application of S, K, N, S + K, K + N, S + N + K moderated the effects of water deficit and increased grain yield by $7.31,2.43,24.39,17.07,10.95$ and $41.46 \%$ compared to the control of the foliar application respectively. Under irrigation after $140 \mathrm{~mm}$ of evaporation, the only significant difference was observed between control treatment and foliar application of $\mathrm{S}+\mathrm{N}+\mathrm{K}$, which increased grain yield by $28.98 \%$ compared to the control (Table 4 ).

It was stated that the increased seed yield can be associated with better vegetative growth, canopy growth, and consequently, better use of sunlight and higher photosynthesis under optimal irrigation conditions (31). Considering the number of capsules per plant, the number of seeds per capsule, and seed weight (considered as the yield components of castor bean), the foliar application of $\mathrm{S}+\mathrm{N}+$ $\mathrm{K}$ in both conditions leads to the maximum seed yield. Due to exposure to favorable conditions, the plant tends to apply favorable environmental conditions, created by foliar application of $\mathrm{S}+\mathrm{N}+\mathrm{K}$ to complete the generative phase. Perhaps the increase in grain yield under normal moisture conditions is due to its effect on the number of capsules per plant directly, and an increase in the number of seeds per plant indirectly $(32,33)$. The foliar spray provides not only nutrients but also a significant amount of water at the time of water stress. In addition to supplying a nutrient for plant growth, $\mathrm{N}$ application could improve the drought tolerance of the plant to enhance yield under water deficit (34). In a study, the highest grain yield and yield components in castor oil were reported at the normal level of irrigation (35).

Late-season foliar $\mathrm{N}$ and $\mathrm{P}$ application in wheat influences grain yield. In the case of the wheat crop (30), It was found that $K$ spray reduced the negative effect of drought on growth and dramatically increased grain yield (36). Foliar utilization of $\mathrm{K}$ was more efficient in alleviating the adverse effect of drought on the grain yield and its components in the wheat crop (19).

An increase in yield and its components in maize with urea foliar application has also been reported $(29,37)$. Moreover, It was also found that $\mathrm{K}$ spray reduced the negative effect of drought on growth and increased grain yield markedly (36).

\section{Oil percent}

The results of the analysis of variance (Table 2 ) indicated that the effects of irrigation levels $(p<0.01)$, on the oil percent were significant. By increasing the irrigation intervals, oil percent was increased, such that the highest oil percent was observed under irrigation after $140 \mathrm{~mm}$ of evaporation by $53.67 \%$ and the least amount was obtained under normal irrigation conditions by $42.50 \%$ (Table 3 ). The foliar application of $\mathrm{S}+\mathrm{N}+\mathrm{K}$ and $\mathrm{S}+\mathrm{N}$ had the most positive effect on oil percent, such that these treatments increased oil percent by 14.22 and $11.49 \%$ compared to the control treatment (Table 3). It was reported that castor seed oil is a genetic trait affected by environmental conditions, crop operations, (6) and harvest time and can be irrigated. These results corroborate the results of the earlier study who observed a significant increase in oil content (42.33\%) in niger due to combined foliar spray of $\mathrm{K}, \mathrm{S}$ and $\mathrm{B}$, along with RDF at 60 DAS (40). The increase in oil content was due to $K$ that enhances the enzyme activity and $S$ as an integral part of the sulph-hydral (-SH) group, which is essential for the biosynthesis of oil; many studies have reported that micronutrient elements can increase the seed oil percentage since they supply the plant's needs and due to the enzymatic activity enhancement, effectively increased photosynthesis by micronutrients and the translocation of assimilates to the seed.

\section{Oil yield}

According to the results of the analysis of variance, the difference between irrigation levels $(p<0.01)$, fertilizers $(p<$ $0.01)$, and their interaction were significant $(p<0.01)$ on oil yield (Table 2). Based on the results of comparing the mean treatments, the highest oil yield was gained from the foliar application of $\mathrm{K}+\mathrm{N}$ and $\mathrm{S}+\mathrm{N}+\mathrm{K}$ fertilizer by 635.75 and $628.6 \mathrm{~kg} / \mathrm{ha}$ under normal irrigation, while the lowest oil yield was observed in irradiation after $140 \mathrm{~mm}$ of evaporation and no foliar application (control) by $340.92 \mathrm{~kg} / \mathrm{ha}$. Like other traits, with increasing the irrigation intervals, oil yield was reduced significantly, but under irrigation after $80 \mathrm{~mm}$ of evaporation, the foliar application of $\mathrm{K}, \mathrm{N}, \mathrm{S}+\mathrm{K}, \mathrm{S}+\mathrm{N}, \mathrm{K}$ $+\mathrm{N}$ and $\mathrm{S}+\mathrm{N}+\mathrm{K}$ fertilizers moderated the effects of water deficit and increased oil yield by 6.64, 30.45, 16.63, 13.39, 18.17 and $21.43 \%$ compared to the control of fertilizer under similar conditions in respective order. In addition, under irrigation after $140 \mathrm{~mm}$ of evaporation, foliar application of $\mathrm{K}+\mathrm{N}$ and $\mathrm{S}+\mathrm{N}+\mathrm{K}$ fertilizer increased grain yield by 25.17 and $33.11 \%$ compared to control fertilizers under similar conditions (Table 4). The higher oil yield might have been due to the better supply of nutrient elements to plants that can increase the seed oil percentage and oil yield. Due to the enhancement of enzymatic activity and micronutrient supply, there is an increased rate of photosynthesis and translocation of assimilates to the seeds (38, 39). Similar results were observed stating that the maximum oil yield of $460.05 \mathrm{~kg} \mathrm{ha}^{-1}$ was obtained following the combined foliar application of $\mathrm{K}, \mathrm{S}$ and $\mathrm{B}$ nutrients with RDF at 50 DAS in the Niger crop (40).

\section{Conclusion}

Water limitation had a negative effect on all the studied characteristics except for oil percent. In this study, water deficit stress reduced grain yield by reducing grain yield components such as the number of capsules per plant, number of grains per capsule and 1000-grain weight. Therefore, irrigation in castor is necessary for achieving maximum grain yield and yield components. In addition, the foliar application of chemical fertilizers had a positive effect on the growth characteristics of castor bean, and the highest values of the traits, other than the 100 -grain weight, were recorded for foliar application of $\mathrm{N}(3000 \mathrm{ppm})+\mathrm{K}$ $(3000 \mathrm{ppm})+\mathrm{S} 2000 \mathrm{ppm})$. Furthermore, this treatment improved grain yield per unit area under normal irrigation and moderate and severe stresses by $62.76 \%, 41.46 \%$, and $28.98 \%$ respectively. It can be concluded that foliar application of $\mathrm{S}+\mathrm{N}+\mathrm{K}$ fertilizer is the best treatment for mitigating some harmful effects of water deficit on castor bean, 
So, $\mathrm{S}+\mathrm{N}+\mathrm{K}$ fertilizer application is recommended for achieving high grain yield in castor.

\section{Acknowledgements}

Thanks to Dr. Safar pour for his valuable comments.

\section{Authors contributions}

All authors collaborated in writing and editing the manuscript

\section{Compliance with ethical standards}

Conflict of interest: The authors declare no conflict of interest.

Ethical issues: None.

\section{References}

1. Weiss EA. Oil seed crops, Ed 2. Black well science, Malden, M.A, 2000; pp 13- 51

2. Ogunniyl DS. Castor oil, A vital industrial raw material. Bioresource Technology. 2006;97: 1086-91. https://doi.org/10.1016/ j.biortech.2005.03.028

3. Mutlu H, Meier MAR. Castor oil as a renewable resource for the chemical industry. Eur J Lipid Sci Technol. 2010;112:10-30. https://doi.org/10.1002/ejlt.200900138

4. Tezara W, Mitchell VJ, Driscoll SD, Lawlor DW. Water stress inhibits plant photosynthesis by decreasing coupling factor and ATP. Nature. 1999; 401: 914-17. https://doi.10.1038/44842

5. Ucan K, Killi F, Gencoglan C, Merdun H. Effect of irrigation frequency and amount onwater use efficiency and yield of sesame (Sesamum indicum L.) under field conditions. Field Crops Res. 2007;101:249-58. https://doi.org/10.1016/j.fcr.2006.11.011.

6. Laureti D, Marras G. Irrigation of castor (Ricinus communis L.) in Italy. Eur J Agron. 1995; 4: 229-35. https://doi.org/10.1016/S11610301(14)80049-X

7. Silberbush LF. Response of maize to foliar vs. soil application of nitrogen-phosphorus-potassium fertilizers. J Plant Nutr. 2002;25:2333-42. https://doi.org/10.1081/PLN-120014698

8. Ling F, Silberbush M. Response of maize to foliar vs. soil application of nitrogen-phosphorus-potassium fertilizers. J Plant Nutr. 2002; 25: 2333-42. https://doi.org/10.1081/PLN-120014698

9. Ihsan MZ, Shahzad N, Kanwal S, Naeem M, Khaliq A, El-Nakhlawy FS. et al. Potassium as foliar supplementation mitigates moisture induced stresses in mung bean (Vigna radiata $\mathrm{L}$.) as revealed by growth, photosynthesis, gas exchange capacity and $\mathrm{Zn}$ analysis of shoot. Int J Plant Prod. 2013;4(S):3828-35. https://doi. 20511914

10. El-Ramady H, Abdalla N, Taha HS, Alshaal T, El-Henawy A, ElHenawy A, et al. (2016a). Selenium and nano-selenium in plant nutrition. Environ Chem Lett. 2016a; 14 (1),123-47. https:// doi.org/10.1007/s10311-015- 0535-1.

11. Manonmani V, Srimathi P. Influence of mother crop nutrition on seed and quality of blackgram. Madras Agric J. 2009; 96 (16): 12528. http:// doi. 2828402980211270348-a-18027447...

12. Haq MU, Mallarino AP. Response of soybean grain oil and protein concentrations to foliar and soil fertilization. Agron J. 2005; 97 (3): 910-18. https://doi.org/10.2134/agronj2004.0215

13. Farahani HA, Valadabadi SA, Daneshian J, Shiranirad AH, Khalvati MA. Medicinal and aromatic plants farming under drought conditions. J Hortic For. 2008;1: 86-92. https://doi.org/10.5897/ JHF. 9000075

14. AOAC. Official methods of analysis: Association of Official Analytical Chemists. 1984; Inc, USA.

15. Holland JB. Estimating genotypic correlations and their standard errors using multivariate restricted maximum likelihood estimation with SAS Proc MIXED. Crop Sci. 2006; 46: 642-54.

16. El-Abady MI, Seadh SE, Attia AN, El-Saidy AEA. Impact of foliar fertilization and its time of application on yield and seed quality of soybean. Proceedings the Sec Field Crops Conference. 2008; 04: 299-313.

17. Yildirim B, Okut N, Türközü D, Terzio $O$, Tunçtürk M. The effects of maxi crop leaf fertilizer on the yield and quality of soybean (Glycine max (L.) Merril). Afr J Biotechnol. 2008; 7: 1903-06. https://doi.10.5897/AJB2008.000-5039.

18. Popović V, Glamočlija Đ, Sikora V, Đekić V, Cervenski J, Simić D et al. Genotypic specificity of soybean (Glicine max. (L.) Merr.) under conditions of foliar fertilization. Rom Agric Res. 2013; 30:1-12. https://doi.10.13140/RG.2.1.4581.6166

19. Aown M, Raza S, Saleem MF, Anjum SA, Khaliq T, Wahid MA. Foliar application of potassium under water deficit conditions improved the growth and yield of wheat (Triticum aestivum L.). J Anim Plant Sci. 2012; 22(2): 431-37. https:// doi.10.1.1.1045.3273\&rep=rep1\&type=pdf

20. Shao HB, Chu LY, Jaleel CA, Zhao CX. Water-deficit stress-induced anatomical changes in higher plants. Comptes Rendus Biologies. 2008; 331: 215-25. https://doi.org/10.1016/j.crvi.2008.01.002

21. Farooq M, Wahid A, Kobayashi N, Fujita D, Basra SMA. Plant drought stress: effects, mechanisms and management. Agron Sustain Dev. 2009; 29:185-212. https://doi.10.1051/agro:2008021.

22. $\mathrm{Xu} Z$ Z, Jiang $\mathrm{Y}$, Jia1 $\mathrm{B}$, Zhou1 $\mathrm{G}$. Elevated $-\mathrm{CO}_{2}$ response of stomata and its dependence on environmental factors. Front Plant Sci. 2016; 13: 1-15. https://doi.org/10.3389/fpls.2016.00657.

23. Bannayan M, Nadjafi F, Azizi M, Tabrizi L, Rastgoo M. Yield and seed quality of Plantago ovata and Nigella sativa under different irrigation treatments. Ind Crops Prod. 2008;27: 11-16. https://doi. 10.1016/j.indcrop.2007.05.002.

24. Schon MK, Blevins DG. Foliar boron applications increase the final number of branches and pods on branches of field-grown soybeans. Plant Physiol. 1990; 92: 602-05. https://doi.10.1104/ pp.92.3.602.

25. Reinbott TM, Blevins DG. Response of soybean to foliar - applied boron and magnesium and soil-applied boron. J Plant Nutr. 2008;18: 179- 200. https://doi.org/10.1080/01904169509364894.

26. Arif M, Chohan MA, Ali S, Gul R, Khan S. Response of wheat to foliar application of nutrients. J Agric Biol Sci. 2006;1(4):30-34.

27. Odeleye FO, Odeleye OMO, Animashaun MO. Effects of nutrient foliar spray on soybean growth and yield (Glycine max (L.) Merrill) in south west Nigeria. Not Bot Horti Agrobot Cluj Napoca. 2007;35:22-32. https://doi.org/10.15835/nbha352205

28. Abdel-Gawad AA, Ashour NI, Saad AOM, Abo-Shetta AM, Ahmed MKA. The insignificant importance of late nitrogen fertilization on the yield of soybean (Glycine max L.) in Egypt. Annual and Agriculture Science Ain Shams University. 1989;33:249-60.

29. Amanullah A, Khan Z, Khan F. Foliar application of nitrogen at different growth stages influence the phenology, growth and yield of maize (Zea mays L.). Soil and Environment. 2013; 32(2): 135-40. https://doi. 10.13140/RG.2.2.25680.30723.

30. Alston AM. Effects of soil water content and foliar fertilization with nitrogen and phosphorus in late seasons on the yield and composition of wheat. Aust J Exp Agric. 1979;30(4):577-85. https://doi.org/10.1071/AR9790577.

31. Filippo L, Moretti A, Lovat A. Seed yield, yield, yield components oil content and essential oil content and composition of Nigella 
sativa L. and Nigella damascenal. Ind Crops Prod. 2002;15 59-69. 37. Amanullah M, Yasir SK, Khalil MT, Jan A, Khan Z. Phenology, https://doi.org/10.1016/S0926-6690(01)00096-6.

32. Akbarinia A, Khosravifard M, Ashorabadi A, Babakhano P. Effect of irrigationon yield and agronomic characteristics of black cumin (Nigella sativa). IJMAPR. 2004;21(1):65-73.

33. liriti M, Picchi V, Rossoni M, Gomarasca S, Ludwig N, Garganoand $\mathrm{M}$ et al. Chitosan anti-transpirant activity is due to abscisic aciddependent stomatal closure. Environ Exp Bot. 2009;66:493-500. https://doi.10.1016/j.envexpbot.2009.01.004.

34. Li WR, Zhang S, Shan L. Effect of water stress on chlorophyll fluorescence parameters and activity of antioxidant enzyme in Alfalfa (Medicago sativa L.) seedlings. In: The First International Conference on the Theory and Practices in Biological Water Saving (ICTPB), 2006. Beijing, China.

35. Guilherme AB, Marcos ABV, Graziane MG, Eder PG, Silvana BS, Anamari $V$ et al. Yield of two castor bean cultivars under different depths of supplemental irrigation. Rev Bras Eng Agric. 2012;16 (9):925-30.

growth and grain yield of maize as influenced by foliar applied urea at different growth stages. J Plant Nutr. 2010; 33(1):71-79. https://doi.org/10.1080/01904160903391099.

38. Movahhedi Dehnavi M, Ranjbar M, Yadavi AR, Kavusi B. Effect of cycocel on proline, soluble sugars, protein, oil and fatty acids of flax (Linum usitatissimum L.) plants under drought stress in a pot trail. Scientific Information Database (SDI). 2009.

39. Ravi S, Channal HT, Hebsur NS, Patil BN, Dharmatti, PR. Effect of sulphur and iron nutrition on growth, yield, nutrient uptake and quality of safflower (Carthamus tinctorius L). Karnataka Journal of Agricultural Science. 2008;21(3):382-85.

40. Lalitha BH, Yeledhalli NA, Ravi MV. Effect of foliar application of potassium sulphate and boric acid on yield, nutrient uptake and quality of Niger (Guizotia abyssinica L.). Karnataka. J Agric Sci. 2006;21(2):282-83.

36. Soad El-Ashry M, El-Kholy M.A. Response of wheat cultivars to chemical desiccants under water stress conditions. J Appl Sci Res. 2005;1:253-62. 